Nig. J. Biotech. Vol. 33 (2017) 131-135

ISSN: 01891731

Available online at

http://www.ajol.info/index.php/njb/index

and www.biotechsocietynigeria.org

DOI: https://dx.doi.org/10.4314/v33i1.19

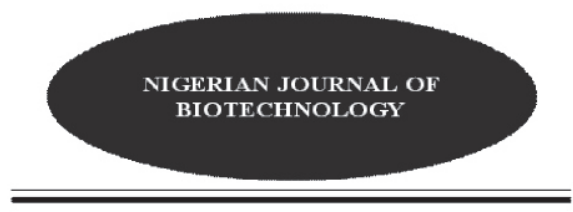

\title{
The levels of yield and purity of genomic DNA from five tomato cultivars subjected to two DNA extraction techniques
}

Ganiyu, S. A. ${ }^{1}$, Yusuf, S. M.1, Agbolade, J. O. ${ }^{2}$ and Imonmion, J. E. ${ }^{3}$

${ }^{1}$ Department of Agronomy, Federal University, Kashere, PMB 0182, Gombe State, Nigeria.

${ }^{2}$ Department of Plant Science and Biotechnology, Federal University, Oye-Ekiti, Ekiti State, Nigeria.

${ }^{3}$ Department of Crop Protection, Federal University of Agriculture, Abeokuta, PMB 2240, Nigeria.

(Received: 09:06:2017; Accepted:29:06:2017

Copyright resides with the authors in terms of the Creative Commons License 4.0.

See http://creativecommons.org/licenses/by/4.0/

Condition of use: The user may copy, distribute, transmit and adapt the work, but must recognize the authors and the Nigerian Journal of Biotechnology

\section{Abstract}

Isolation of good quality genomic DNA from different plant materials is an important prerequisite for many molecular techniques related to both basic and applied research in the areas of plant molecular biology, crop improvement, biodiversity studies and conservation of genetic materials. Therefore, the need to extract reasonably pure DNA of both good quality and quantity for the downstream successful DNA-based diagnostic techniques is required. In this study, yield and purity of the extracted DNAs, using Dellaporta et al. (1983) and the use of Zymo Research Plant/Seed DNA MiniPrep Kit (ZR kit), were quantified with Nanodrop spectrophotometer and on agarose gel after polymerase chain reaction (PCR) amplification. The results of the DNA yield and purity were in the range of 24.42 to $1430.52 \mathrm{ng} / \mu \mathrm{l}$ and 1.11 to 2.00 , respectively. The outstanding DNA yield in Kerewa cultivar in yield (1430.52 $\mathrm{ng} / \mu \mathrm{l})$ and purity (1.99) makes it appropriate for downstream DNA-based diagnostic techniques in biotechnology research. On agarose gel DNA bands appeared to be compact with negligible smearing with Dellaporta et al. method indicating good quality of DNA. The results demonstrated that good yield of very pure, intact, high quality genomic DNA could be obtained from tomato leaves using the method of Dellaporta et al.

Keywords: DNA, extraction, purity, tomato, yield.

Correspondence: ganiyu.sikiru@yahoo.com; +234-8136392050.

\section{Introduction}

DNA extraction is a routine step in many biological studies including molecular identification, phylogenetic inference, genetics, and genomics. Isolation of good quality genomic DNA from different plant materials is an important prerequisite for many molecular techniques related to both basic and applied research in the areas of plant molecular biology, crop improvement, biodiversity studies and conservation of genetic materials (Kumari et al., 2012). Also, Kumari et al. (2012) identified that apart from quality, overall yield is also important for various applications. Extracted DNA that is pure give good polymerase chain reaction (PCR) products compared to DNA with lower purity which requires several dilutions before it will give a good PCR product (Turaki etal., 2017). Ecology of southwestern Nigeria is very favorable for tomato production. It is an economic fruit vegetable for tomato growers, consumed fresh and also used to manufacture a wide range of processed products. Unfortunately, many cultivars grown are susceptible to bacterial and fungal diseases. One of the most challenging is bacterial wilt caused by Ralstonia solanacearum. This disease can constitute up to $100 \%$ yield loss in endemic areas (Popoola et al., 2015). Moreover, due to the effect of this destructive disease, most tomato fruits are transported from northern part of the country to southern states and have continued to increase each year. However, breeding for resistance against diseases is very challenging. Breeding a resistant variety using an updated gamplasm as a donor typically requires a series of backcrosses to the cultivated recurrent parent to combing desirable characteristics. This procedure is time consuming. To start with, the application of molecular breeding through extraction 
high quality DNA makes it simplified even for numerous samples.

Genetic analyses of plant rely on high yields of pure DNA samples. In Some plant species, DNA extraction is difficult because of contents of polyphenols and other secondary metabolites ( Zhang and Stewart, 2000; Dehestani and Tabar, 2007; Sahasrabudhe and Deodhar, 2010; Srivastava et al., 2010; Okpodu and Abdullah-Israel, 2011). During the DNA isolation protocols, higher quality and yield are two important factors. The DNA isolation protocols include some similar steps. The main purpose is to separate DNA from other compounds especially proteins, carbohydrates, phenols and other polysaccharides (Atak et al., 2014). After DNA extraction, it is important to determine purity and yield. The DNA isolated in pure form is used in different molecular studies and different purposes (Varma et al., 2007; Tiwari et al., 2012).

DNA isolation and purification are two important steps for molecular biology studies (Arif et al., 2010). Like reagents, good quality DNA is an essential to achieve good results in experiments, especially in the Polymerase Chain Reaction (PCR), in which excess of cell debris and proteins may inhibit the amplification (Baise et al., 2002). Many molecular biology techniques and investigations require genomic DNA as a starting material (Vaseemuddin, 2010). The degree of purity and quality can vary from plant and isolation protocols. Many different methods and technologies are available for the isolation of genomic DNA (Atak et al., 2014). Different methods have been developed for genomic DNA isolation depending on the nature and complexity of the plant materials (Sharma et al., 2008). Similarly particular leaf textures and types can impede extraction of DNA (Mirbahar et al., 2014). This connotes that different genotypes/cultivars respond differently to methods of DNA isolation. In this study, yield and purity of DNA from five tomato cultivars (F1-Mongal, Pure-water, Santana, Kerewa and Tyre-type) were compared using Dellaporta et al. (1983) and a commercially available Zymo Research Plant/Seed DNA MiniPrep Kit.

\section{Materials and Methods}

Experimental site

The experiment was carried out at the International Institute of Tropical Agriculture (IITA), Ibadan. Nigeria.

\section{Plant materials for DNA isolation}

The seeds of five tomato cultivars (F1Mongal, Pure-water, Santana, Kerewa and Tyre-type) were grown under screenhouse conditions and apical leaves were harvested from two-week old seedlings for DNA isolation. Fresh leaf tissue $(150 \mathrm{mg})$ was weighed on an electronic metlar balance and ground into a fine powder in liquid nitrogen with a pestle and mortar, transferred into a $1.5 \mathrm{ml}$ tube and temporarily stored at $-20^{\circ} \mathrm{C}$.

\section{Genomic DNA Extraction}

Dellaporta et al. (1983) and Zymo Research Plant/Seed DNA MiniPrep Kit (ZR kit) were used.

Method 1: DNA isolation procedures followed Dellaporta et al. (1983) with little modification made on the amount of reagents used. To each tube containing ground tissue $(150 \mathrm{mg}), 700 \mu \mathrm{l}$ of hot $\left(65^{\circ}\right.$ C) plant extraction buffer (PEB)(637.50 ml dd $\mathrm{H}_{2} \mathrm{O}$, $100 \mathrm{ml} 1 \mathrm{M}$ Tris-HCl, PH 8.0, $100 \mathrm{ml} 0.5 \mathrm{M}$ ethylenediaminetetra acetic acid (EDTA) , PH 8.0, 100 $\mathrm{ml} 5 \mathrm{M} \mathrm{NaCl}$ and $62.50 \mathrm{ml}$ 20\% Sodium Dodecyl Sulphate (SDS)) was added. One percent Bmercaptoethanol was added to the pre-warm PEB just before use. The tubes were capped and inverted gently 6-7 times to mix the sample with the buffer. The solution was incubated at $65^{\circ} \mathrm{C}$ in water bath for 20 mins with occasional mixing to homogenize the samples. After, it was removed and uncapped. The tubes were allowed to cool at room temperature for 2 mins. $500 \mu \mathrm{l}$ of $5 \mathrm{M}$ ice-cold potassium acetate $\left(\mathrm{CH}_{2} \mathrm{COOK}\right)$ was added and recapped, mixed and incubated on ice-cold for 20 mins. It was then spinned at 12,000 rpm for $10 \mathrm{~min}$ and supernatant was transferred into new tubes. Chloroform isoamyl $(700 \mu \mathrm{l}$ ) was added and spinned at 10,000 rpm for 10 mins and supernatant transferred to another new tube. Ice-cold isopropanol $(700 \mu \mathrm{l})$ was added, gently mixed and stored in a freezer $\left(-20^{\circ} \mathrm{C}\right)$ for $1 \mathrm{hr}$ to precipitate the DNA and then centrifuged at 12,000 rpm for 10 mins. The supernant was carefully discarded; tube was drained on clean paper towel for 1 hour.

The DNA pellet was washed twice in $100 \mu \mathrm{l}$ cold $70 \%$ ethanol for 20 mins and air dry completely. Sixty microlitre $(60 \mu \mathrm{l})$ of sterile distilled water was added to the pellet, followed by 2 ul of $10 \mathrm{ng} / \mathrm{ml}$ RNase. The final incubation of the solution was done for 40 mins at $37^{\circ} \mathrm{C}$ with gentle mixing at 10 mins intervals. The DNA was stored in $-20^{\circ} \mathrm{C}$.

Method 2: Zymo Research Plant/Seed DNA MiniPrep Kit (ZR Kit) was used, according to the manufacturer's protocol. Fresh tomato leaf of $150 \mathrm{mg}$ was added to a ZR BashingBead ${ }^{T M}$ Lysis Tube and $750 \mu$ l Lysis Solution added. Disruption of the cells was done at high speed for $10 \mathrm{~min}$. The Lysis Tube was then centrifuged in a microcentrifuge at $10,000 \times \mathrm{g}$ for $1 \mathrm{~min}$. About $400 \mu \mathrm{l}$ supernatant was transferred to Zymo-Spin ${ }^{\mathrm{TM}}$ IV Spin Filter (orange top) in a Collection tube and centrifuged at 7,000 rpm $(\sim 7,000 \times \mathrm{g})$ for $1 \mathrm{~min}$. 
Thereafter, 1,200 $\mu \mathrm{l}$ of Plant/Seed DNA Binding Buffer (diluted with beta-mercaptoethanol to a final solution of $0.5 \% \mathrm{v} / \mathrm{v}$ ) was added to the filtrate in the collection tube and mixed with micropipette. From the Collection tube, $800 \mu \mathrm{l}$ of the mixture was transferred to Zymo-Spin ${ }^{\mathrm{TM}}$ IIC Column in a Collection tube and centrifuged at $10,000 \times \mathrm{g}$ for $1 \mathrm{~min}$.

The flow through was discarded and $200 \mu \mathrm{l}$ DNA Pre-Wash Buffer was added to the Zymo-Spin ${ }^{\text {TM }}$ IIC Column in a new Collection tube and centrifuged at $10,000 \times \mathrm{g}$ for $1 \mathrm{~min}$. Plant/Seed DNA Wash Buffer, $500 \mu \mathrm{l}$, was added to the Zymo-Spin ${ }^{\mathrm{TM}}$ IIC Column and centrifuged at $10,000 \times \mathrm{g}$ for $1 \mathrm{~min}$. Zymo-SpinTM IIC Column was transferred to clean $1.5 \mathrm{ml}$ microcentrfuge tube and $100 \mu$ DNA Elution Buffer was added directly to the column matrix and centrifuged at $10,000 \times \mathrm{g}$ for $30 \mathrm{sec}$ to elute the DNA. The eluted DNA from was transferred to a centrifuged Zymo-spin ${ }^{\text {TM }}$ IV-HRC Spin Filter (green top) in a clean $1.5 \mathrm{ml}$ microcentrifuge tube and centrifuged at exactly $8,000 \mathrm{xg}$ for $1 \mathrm{~min}$.

\section{Gel electrophoresis and spectrophotometry}

Agarose gel (1\%) was prepared, microwaved at $100^{\circ} \mathrm{C}$ for 3 mins. and allowed to cool. Five microlitre of ethidium bromide (EtBr) was added to $150 \mathrm{ml}$ agarose gel, poured into the gel tank and allowed to solidify. Subsequently, $3 \mu$ l of loading dye was added to $5 \mu$ leach of the samples. Samples were loaded and allowed to run at $100 \mathrm{~V}$ for $45 \mathrm{~min}$ before viewing on UV light source and photographed. The quality of the extracted samples was evaluated by the ratio of the absorbance at 260 and $280 \mathrm{~nm}$.

\section{Results}

Table 1 shows the quantity and purity of the extracted genomic DNA from five tomato cultivars using two different extraction methods. In ZR Kit extraction, genomic DNA concentrations ranged from 24.42 to $43.11 \mathrm{ng} / \mu \mathrm{l}$ with highest concentration of $43.11 \mathrm{ng} / \mu \mathrm{l}$ in Pure-water cultivar and $24.42 \mathrm{ng} / \mu \mathrm{l}$ in F1-Mongal cultivar. It was observed that Kerewa had a unique DNA yield $(1430.52 \mathrm{ng} / \mathrm{\mu l})$ above other cultivars using Dellaporta et al. protocol; with Purewater cultivar produced the least yield of 687.51 $\mathrm{ng} / \mathrm{\mu l}$. In all, the highest amount of DNA was obtained from Kerewa $(1430.52 \mathrm{ng} / \mu \mathrm{l})$ while on the other hand F1-Mongal cultivar produce the least amount of DNA $(24.42 \mathrm{ng} / \mathrm{\mu l})$. DNA purity ranged from 1.11 to 2.00 in both methods. DNA purity from all tomato samples, when Dellaporta et al.method was used, ranged from 1.73 to 2.00 . The genomic DNA samples from different plant materials were determined on agarose gel (Plate $1 \mathrm{~A}$ and $\mathrm{B})$. The DNA bands appeared to be compact with negligible smearing indicating little degradation during isolation (Plate $1 \mathrm{~A}$ ) but there were smeared bands of DNA in Plate 1B. Dellaporta et al. method presented highly resolved bands indicating good quality of DNA (Plate $1 \mathrm{~A})$.

Table 1: Comparison of genomic DNA quantity and purity extracted using two different extraction methods.

\begin{tabular}{llllllll}
\hline $\mathbf{S / N}$ & $\begin{array}{l}\text { Cultivar } \\
\text { Name }\end{array}$ & $\begin{array}{l}\text { Age } \\
\text { (wee } \\
\mathbf{k})\end{array}$ & $\begin{array}{l}\text { Amount of } \\
\text { leaf sample } \\
\mathbf{( g )}\end{array}$ & \begin{tabular}{l} 
Concentration $\mathbf{( n g / \mu l )}$ \\
\cline { 5 - 7 }
\end{tabular} & & & $\begin{array}{l}\text { Purity of DNA } \\
\text { (A260/A280) }\end{array}$ \\
\cline { 5 - 7 } & & & $\begin{array}{l}\text { ZR Kit } \\
\text { method }\end{array}$ & $\begin{array}{l}\text { Dellaporta et } \\
\text { al., method }\end{array}$ & $\begin{array}{l}\text { ZR Kit } \\
\text { method }\end{array}$ & $\begin{array}{l}\text { Dellaporta et } \\
\text { al., method }\end{array}$ \\
\hline $\mathbf{1}$ & F1-Mongal & 2 & 1.50 & 24.42 & 871.50 & 1.11 & 1.99 \\
$\mathbf{2}$ & $\begin{array}{l}\text { Pure- } \\
\text { water }\end{array}$ & 2 & 1.50 & 43.11 & 687.51 & 1.33 & 1.73 \\
$\mathbf{3}$ & Santana & 2 & 1.50 & 25.33 & 798.18 & 1.22 & 2.00 \\
$\mathbf{4}$ & Kerewa & 2 & 1.50 & 27.25 & 1430.52 & 1.24 & 1.99 \\
$\mathbf{5}$ & Tyre-type & 2 & 1.50 & 36.18 & 924.65 & 1.45 & 1.92 \\
\hline
\end{tabular}




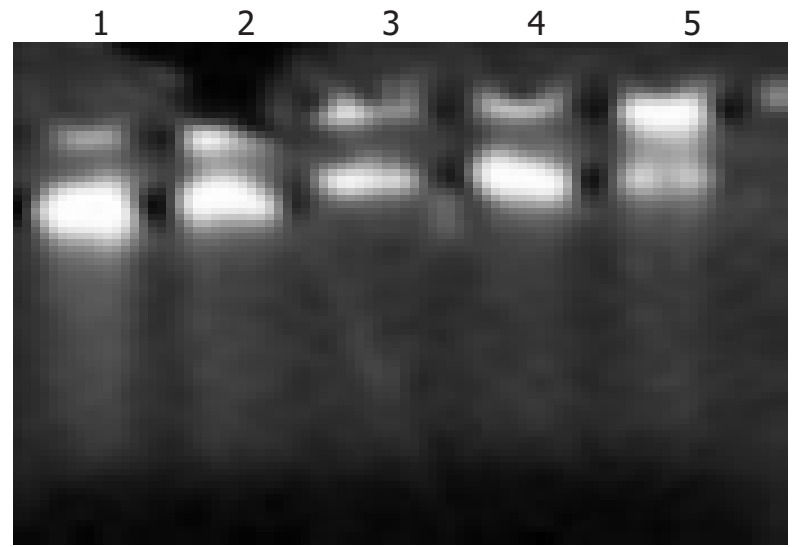

Plate $1 \mathrm{~A}$ : Agarose gel electrophoresis of the products obtained using a Dellaportal et al. method of DNA extraction from tomato leaf samples. Lane 1: F1-mongal; 2: Pure-water; 3: Santana; 4: Kerewa and 5: Tyre-type. DNA extracts were electrophoresed on $1 \%$ agarose gel at $100 \mathrm{~V}$ for 45 min, stained with ethidium bromide and visualized under UV illumination.

\section{Discussion}

Three contaminants associated with plant DNA can interfere PCR reactions, for example polyphenolic compounds, polysaccharides and RNA (Krishna et al., 2012) and these can hamper the isolation of good quality DNA (Arif et al., 2010). For molecular genetic analysis of crops, availability of high-quality cellular DNA is an essential precondition. When Dellaporta et al. method was used good quality DNA was extracted from Santana, F1-Mongal, Kerewa, Tyre-type and Pure-water cultivars which showed that contaminants were not present. This corroborated the report of Mirbahar et al. (2014) that good quality DNA isolation is necessary which is comparatively free from several contaminants found in plant cells. Pich and Schubert (1993) described DNA purity in the range of $1.6-1.7$ the absence of contaminants. In this study, the results indicated that DNA extracted using ZR kit were contaminated. Mirbahar et al. (2014) further stated that extraction of intact, high molecular-weight DNA that can support $P C R$, genomic blot analysis, fingerprinting and other molecular analysis is not easy when the plant tissue is rich in polysaccharides, secondary metabolites or polyphenolics. The results of the PCR when commercial kit was used might be due to high amount of proteins in the plant which might bind firmly to nucleic acids during extraction of DNA which the commercial kit could not resolve. This was similar to the work of previous researchers who identified that high amount of proteins is present in many plant species naturally (Angeles et al., 2005) and other substances could bind firmly to nucleic acids during

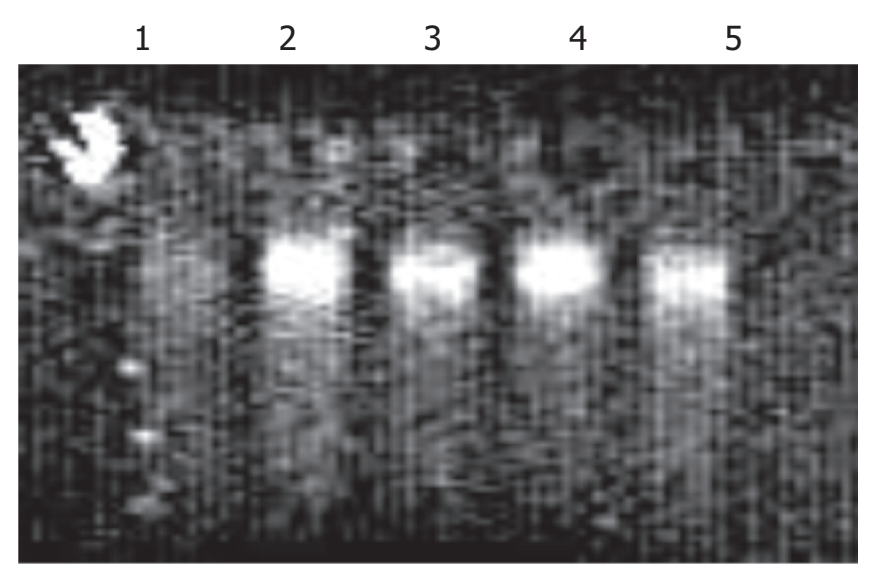

Plate $1 \mathrm{~B}$ : Agarose gel electrophoresis of the products obtained using Zymo Research Plant/Seed DNA MiniPrep Kit methods of DNA extraction from tomato leaf samples. Lane 1: F1-mongal; 2: Pure-water; 3: Santana; 4: Kerewa and 5: Tyre-type. DNA extracts were electrophoresed on $1 \%$ agarose gel at $100 \mathrm{~V}$ for $45 \mathrm{~min}$, stained with ethidium bromide and visualized under UV illumination.

extraction of DNA which can interfere in DNA amplification (Ribeiro and Lovato, 2007).

To use methods common to different genotypes can help rapidly. In this study, different tomato cultivars DNA quantity and purity were used. Genomic DNA extracted from F1-Mongal, Pure-water, Santana, Kerewa and Tyre-type with Dellaporta et al. method of DNA isolation produced better results. The yield and purity from samples using ZR kit were lower, suggesting the presence of impurities. Agarose gel comparison of DNA also indicated the presence of degraded or smeared DNA in the samples from ZR kit as shown by the smeared appearance of the DNA on the gel. The results demonstrated that good yields of very pure, intact, high quality genomic DNA could be isolated from tomato leaves using the method of Dellaporta et. al.

\section{References}

Angeles, J.G.C., Laurena, A.C. and Tecson-Mendoza, E.M. (2005). Extraction of Genomic DNA from the lipid, polysacchardide and polyphenol rich coconut (Cocos nucifera L.). Plant Mol. Biol. Rep. 23: 297-297.

Arif, I.A., Bakir, M.A., Khan, H.A., Ahamed, A., AlFarhan, A.H., Al-Homaidan, A.A., Al-Sadoon, M., Bakhali, A.H. and Shobrak, M. (2010). A simple method for DNA extraction from mature date palm leaves: impact of sand grinding and composition of lysis buffer. Int. J. Mol. Sci. 11: 3149-3157.

Atak, A., Kaya, E. and Erken, K. (2014). Determination of Quantity and Purity of Some Geophytes DNA 
Collected from the Flora of Turkey. Asian Journal of $\mathrm{P}$ I a n t S c i e nce s, $13: 98$ 110.DOI: 10.3923 /ajps.2014.98.110 http://scialert.net/abstract/?doi=ajps.2014.98.110

Biase, F.H., Franco, M.M., Goulart, L.R. and Antunes, R.C. (2002). Protocol for extraction of genomic NA from swine solid tissues. Genet. And Mol. Biol., 25, 313-315.

Dehestani, A. and Tabar, S.K.K. (2007). A rapid efficient method for DNA isolation from plants with high levels of secondary metabolites. Asian J. Plant Sci., 6: 977-981.

Dellaporta, S. L., Wood, J. and Hicks, J. B. (1983). A Plant DNA Minipreparation: Version II. Plant Mol. Biol. $\mathrm{R}$ e $\mathrm{p}$. , $1: 19-21$. http://dx.doi.org/10.1007/BF02712670

Krishna R.B., Reddy, S.R.R., Javangula, H., Swapna, D., Reddy, K.J. (2012). An easy and simple method of isolation and purification of genomic DNA from the leaves of Gymnema sylvestre an anti-diabetic plant. Int. J. Life Sci. \& Pharma Res. 2(1): 15-20.

Kumari, V., Bansal, A., Aminedi, R., Taneja, D. and Das, N. (2012). Simplified extraction of good quality genomic DNA from a variety of plant materials. Afr. J. Biotechnol. 11(24):6420-6427, http://www.academicjournals.org/AJB, DOI: 10.5897/AJB11.2366

Mirbahar, A.A., Khan, S., Saeed, R., Kauser, N., Jahan, B. and Markhand, G. S. (2014). DNA Extraction And Optimization From Fibrous Leaves Of Some Date Palm Cultivars From Pakistan. FUUAST J. Biol., 4(2): 119122

Okpodu, C.M. and M. Abdullah-Israel, (2011). A DNA isolation protocol suitable for RAPD analysis from fresh or herbarium-stored leaves of a historic Quercus virginiana L. J. Plant Sci., 6: 77-87.

Pich, U. and Schubert, I. (1993). Mini preparation method for isolation of DNA from plants with a high content of polyphenols. Nucleic Acid Res. 21: 3328.

Popoola, A. R., Ganiyu, S. A., Enikuomehin, O. A., Bodunde, J. G., Adedibu, O.B., Durosomo, H. A. and Karunwi, O. A. (2015). Isolation and Characterization of Ralstonia solanacearum Causing Bacterial Wilt of Tomato in Nigeria. Nig. J. Biotechnol. 29:1 - 10.
Published by Biotechnology Society of Nigeria. http://www.ajol.info/index.php/njb/index and www.biotechsocietynigeria.org, DOI: http://dx.doi.org/10.4314/njb.v29i1.1

Ribeiro, R.A. and Lovato, M.B. (2007). Comapartive analysis of different DNA extraction protocols in fresh and herbarium specimens of the genus Dalbergia. Genet and Mol. Res. 6(1): 173-187

Sahasrabudhe, A. and Deodhar, M. (2010). Standardization of DNA extraction and optimization of RAPD-PCR conditions in Garcinia indica. Int. J. Bot., 6: 293-298.

Sharma, K., Mishra, A. K., Misra, R. S. (2008). A simple and efficient method for extraction of genomic DNA from tropical tuber crops. Afr. J. Biotechnol. 7: 10181022.

Srivastava, N., Sharma, V., Kamal, B., Dobriyal, A.K. and Jadon, V.S. (2010). Polyphenolics free DNA isolation from different types of tissues of Aconitum heterophyllum wall-endangered medicinal species. J. Plant Sci., 5: 414-419.

Tiwari, K.L., Jadhav, S.K. and Gupta, S. (2012). Modified CTAB technique for isolation of DNA from some medicinal plants. Res. J. Med. Plant, 6: 65-73.

Turaki, A. A., Ahmad B., Magaji, U. F., Abdulrazak U. K., Yusuf B. A. and Hamza A. B. (2017) Optimised cetyltrimethylammonium bromide (CTAB) DNA extraction method of plant leaf with high polysaccharide and polyphenolic compounds for downstream reliable molecular analyses. Afr. J. Biotechn. 16(24):1354-1365. DOI: 10.5897/AJB2017.15942

Varma, A., Padh, H. and Shrivastava, N. (2007). Plant genomic DNA isolation: An art or a science. Biotechnol. J., 2: 386-392.

Vaseemuddin, S. (2010). DNA extraction from pulp tissues for its application in PCR. A study to extract DNA with high purity as quantified by gel electrophoresis. World J. of Dentistry. 1(2):85-88.

Zhang, J. and Stewart, J.M. (2000). Economical and rapid method for extracting cotton genomic DNA. J. Cotton Sci., 4: 193-201. 